\title{
LATIN AMERICAN SPACE RESEARCH \\ - CHALLENGES AND OPPORTUNITIES
}

\author{
JoAnNa GocŁowsKa-BoleK \\ American Studies Center, University of Warsaw, ul. Krakowskie Przedmieście 26/28, 00-927 Warsaw \\ j.goclowska-bolek@uw.edu.pl
}

\begin{abstract}
The interest of Latin American countries in space research has been successfully developing for many decades. It has its roots in the first development programmes for the Brazilian and Argentinian defence industry within the import substitution strategy, and then the export-oriented strategy during the period of the military rule. The endogenous development of space technology was treated in those countries as a priority and served as a way to diffuse technology to other industries, and as a model for the other countries in the region (Peru and Venezuela), which wished to develop outer space programme by developing their own technologies within the chosen range or by partaking in broader cooperation programmes on the Latin American continent [1]. The Latin American space agencies, which already existed in many countries in the 1960s and the 1970s, were carrying out relatively costly research, treating development in this area not only as the achievement of the economic development objectives, but also as an attempt to oppose the dominance of Washington [2]. Despite of the vast funding on endogenous research in the field of space engineering being provided, until the end of the last century only the projects conducted together with the Soviet Union (Cuba) or The United States were accomplished successfully. Currently and in the nearest future, the Latin American countries are still forced to rely on external assistance with satellite launching, expertise, more advanced technologies, etc. It should be noticed that countries conducting advanced and costly space programmes: the United States, Russia, China and the European Union (especially France and - but to a substantially lesser degree - Italy) show a growing interest in cooperation with Latin America and appreciation towards their specialists, high quality research and space technologies.

Keywords: Latin America, Brazil, space research, innovation, scientific cooperation.
\end{abstract}




\section{THE INTEREST OF LATIN AMERICA IN SPACE RESEARCH}

Latin America has been paying great attention to the conquest of space for a long time. The first Latin American astronaut was a Cuban, Arnaldo Tamayo Mendez, who took part in the Sojuz 38 mission, carried out by the Soviet Union in 1980. A Mexican Rodolfo Neri Vela took part in STS-61-B mission in 1985, and a Costa Rican Franklin Chang-Diaz, physicist and astronaut associated with MIT in the United States, since 1986 has been taking part in seven space missions conducted by NASA. Franklin Chang-Diaz is also a physics professor at the Rice University and the University of Houston, as well as the director of Advanced Space Propulsion Laboratory in Johnson Space Center (from the beginning, namely since 1979, he has been managing the work on the VASIMR drive and leading advanced research in the area of the thermonuclear technology and plasma drive). The first Latin American woman, who took part in the expedition into outer space (in 1993), was Ellen Ochoa, an American female engineer and astronaut, currently the director of Johnson Space Center in the USA, as well as a member of National Science Board [3]. The first Brazilian astronaut was Marcos Pontes (in 2006 he flew to the International Space Station Sojuz TMA 8 within the Expedition-13 mission), and the first Peruvian astronaut - Carlos Noriega, who took part in the STS-84 mission in 1997. The first Puerto Rican astronaut, Joseph Acaba, ventured into space in 2009 within the STS-119 mission. The full list of Latin American astronauts, including esteemed researchers working in Latin American and North American space centres, is obviously longer.

A significant event which confirmed Latin American space conquest aspirations took place during the meeting of the defence ministers of the Union of South American Nations (in Spanish: Unión de Naciones Suramericanas, UNASUR), which was held in November 2011, in Lima. The leaders of the Latin American countries agreed on a common objective, which was the establishment of the South American Space Agency. The Minister of Defence of Argentina, Arturo Puricelli, stated that research cooperation within UNASUR significantly decreased costs for all the participating countries and would enable exchange of the information and running international projects, such as satellite launching. In the presence of the Brazilian Minister of Defence and with his support, Argentinean Arturo Puricelli stated that "the idea of the South American Space Agency is not supposed to become the imitation of the European one, but to be our own idea of defence, where we have much more defence from and control of space [4]. After the Brazilian defence industry in 1990s bankrupted, Brazil and Argentina started soliciting for a merger of potentials of the South American countries, focusing mostly on cooperation within Mercosur [5] in the first decade of the new century, and seemingly trying to improve cooperation in the UNASUR structures since 2011.

Space research agencies successfully operate in many Latin American countries. Some of them were set up in 1960s and 1970s, and part of them was transformed or started working in recent years.

The value of the space market is estimated at 330 billion USD globally. Many developed countries allocate significant funds to the space industry, considering it as a strategic one. The world leaders of the space research, the United States and Russia, devote $0.25 \%$ of their GDP for that purpose.

The Latin American agencies invest in space programmes more than 500 million USD annually (based on data from the official agency websites). Although this amount is not impressive in comparison with the NASA's annual budget, which is 19 billion USD [7], it enables 
to conduct expensive endogenous research projects. In 1980s and 1990s Brazil invested almost 1 billion USD in the development of research infrastructure of the National Institute for Space Research (INPE). Which made the launch of the first scientific satellite constructed in Brazil in 1993 (SCD-1), possible. The Argentinean scientific satellite (SAC-B) was launched shortly afterwards, in 1996. Its mission was to conduct research in astrophysics and solar physics. Both countries have already reached a critical mass of scientific infrastructure and skills required to globally dominate some space technologies. Both also show determination to complete the space technology chain: from materials science, technical design, remote sensing, synthetic aperture radar design, to telecommunication, image-processing and transformation technology. There is fierce rivalry between Argentina and Brazil for space research, although there are various initiatives conducted together. For example, since 2011 the Argentinian CNEA and Brazilian CNEN have been working together on two $30 \mathrm{MW}$ nuclear research reactors, Both reactors are supposed to produce radioisotopes, test fuel and materials irradiation as well as do research on neutron beams, and will be prepared based on an improved version of the OPAL reactor designed by INVAP for Australian Nuclear Science and Technology Organization (ANSTO) in April 2007 [8].

Tab. 1. Space agencies in Latin America

\begin{tabular}{|c|l|l|c|c|}
\hline State: & \multicolumn{1}{|c|}{ Name of the agency in English: } & \multicolumn{1}{|c|}{ Original name of the agency: } & Abbreviation: & $\begin{array}{c}\text { Established } \\
\text { in: }\end{array}$ \\
\hline Argentina & National Commission of Space Research & Comisión Nacional de Investigaciones Espaciales & CNIE & 1960 \\
\hline Brazil & National Commission of Space Activity & Comissão Nacional de Atividades Espaciais & CNAE & 1963 \\
\hline Brazil & National Institute of Space Research & Instituto Nacional de Pesquisas Espaciales & INPE & 1971 \\
\hline Peru & Peruvian Space Agency & Agencia Espacial del Perú & CONIDA & 1974 \\
\hline Uruguay & $\begin{array}{l}\text { Aeronautical-Space Research and } \\
\text { Dissemination Center }\end{array}$ & $\begin{array}{l}\text { Centro de Investigación y Difusión Aeronáutico- } \\
\text { Espacial }\end{array}$ & CIDA-E & 1975 \\
\hline Argentina & Public Institute of Nuclear Technologies & & INVAP & 1976 \\
\hline Argentina & National Commission of Space Activity & Comisión Nacional de Actividades Espaciales & CONAE & 1991 \\
\hline Mexico & $\begin{array}{l}\text { Institute of Space Research at the National } \\
\text { Autonomous University of Mexico }\end{array}$ & $\begin{array}{l}\text { Instituto de Investigación Espacial de } \\
\text { Universidad Nacional Autónoma de México }\end{array}$ & UNAM & 1991 \\
\hline Brazil & Brazilian Space Agency & Agência Espacial Brasileira & AEB & 1994 \\
\hline Colombia & Colombian Space Commission & Comisión Colombiana del Espacio & CCE & 2006 \\
\hline Venezuela & Bolivian Commission of Space Activity & Agencia Bolivariana para Actividades Espaciales & ABAE & 2008 \\
\hline Costa Rica & $\begin{array}{l}\text { Central American Association of Aeronautics } \\
\text { and Space }\end{array}$ & $\begin{array}{l}\text { Asociación Centroamericana de Aeronáutica y el } \\
\text { Espacio }\end{array}$ & ACAE & 2010 \\
\hline Mexico & Mexican Space Agency & Agencia Espacial Mexicana & AEM & 2010 \\
\hline Bolivia & Bolivian Space Agency & Agencia Boliviana Espacial & ABE & 2012 \\
\hline
\end{tabular}

Source: Own elaboration based on [6] and web resources.

ARSAT-1, the first telecommunication satellite was created in Latin America and launched in October 2014. To build it, INVAP devoted 250 million USD. Thanks to this achievement Argentina has become one of ten countries, which has so advanced space technology. It is the first of three geosynchronous satellites constellations, which will be used not only by Argentina, but also by other countries in the region. ARSAT-2 was launched in September 2015, and ARSAT-3 is supposed to be launched in 2017 [9]. 


\section{SPACE RESEARCH AS A SOURCE OF INNOVATION}

Space research conducted in Latin America introduced a new generation of scientific satellites. Satellites SAOCOM 1 and SAOCOM 2 will use remote sensing data, which are collected by radars designed and produced in Argentina. The SARA (Argentine Air Robotic System) project is also in advanced stage, its aim is to widen active remote Earth observation by applying microwave and optical radars [10]. The programme for the Long Range 3D Primary Radar Prototype (RP3DLAP) construction was successfully completed in 2014, it was also the beginning of the construction programme of the 3D Argentine Monopulse Secondary Surveillance Radar(RSMA), for the Argentinian military forces and civil aviation [11]. Argentina also does an advanced research on the new liquid fuels missile technologies (in Spanish: Inyector Satelital de Cargas Utiles Ligeras, in English: Light Payloads Satellite Launcher) used in TRONADOR I and II missiles (in the nearest future also in TRONADOR III missiles) [12].

The showcase of Latin American space research, the use of space technology innovations for a balanced environment, and an evident reason to be proud is the Brazil SIVAM project (The Amazonia Monitoring System, in Portuguese: Sistema de Vigilância da Amazônia). SIVAM was initially developed - since the beginning of 1990 - as a system to monitor the environmental changes in Amazonia and to mark its potential for change, including: deforestation, fire, air and water pollution. SIVAM supervises more than two million square miles of rainforests and is considered as the biggest monitoring and environmental programme in the world. This system was started in 2002, and was fully developed two years later. SIVAM is controversial, as it is used to limit the production and distribution of drugs as well as to reduce illegal logging and the burning of rainforests.

In 1997 an agreement was reached between foreign partners: Raytheon Company, which is a military agency from the United States, and MacDonald Dettwiler (MDA), a Canadian airline company, which together with Brazil ASTECH and Embraer started building infrastructure and screening programmes. On the basis of the agreement Amazonian Protection System (SIPAM, in Portuguese: Sistema de Proteção da Amazônia) was established, consisting of fixed networks and mobile ground radars as well as aerial surveillance which uses Embraer ERJ 145 and space satellites, connected into platform called R-99 [13]. The initiative is criticised for irregularities, corruption and too high funds devoted to the system which cannot be even fully used, as there are not enough specialists who are able to analyse and interpret gathered data. Still, SIWAM is regarded as one of the most important elements of environmental infrastructure not only in Brazil, but on a global scale.

Brazil treats the development of space technologies programme extremely seriously and undoubtedly it is one of the main areas where innovations are created, not only in Brazil, but in the whole Latin America. As the only country in the region, it carries out systematic research works and invests vast funds since 1960s. It wants to design an independent space programme and has ambitions to achieve this aim by its own space centre called Alcântara Launch Center (in Portuguese: Centro de Lançamento de Alcântara, CLA), in Maranhão. Unfortunately, the Brazilian space centre and two finished satellites were destroyed in the 2003 explosion that 
killed 21 people, mostly highly qualified engineers and technicians. The investigation revealed that the accident was caused by serious mistakes in the project management and insufficient funding, which in combination with a considerable lack of experience, protections and procedures led to disaster, negating many years of preparation and causing huge material losses. Reconstruction of presently existing infrastructure costed approximately 300 million USD. The explosion called into question not only the space technology development in Brazil, but also it sparked discussion about the validity of this costly programme. However, in October 2004, 14 months after the explosion in Alcântara, Brazil sent its first missile in space, VSB-3, and in December 2007 in cooperation with Argentina - which also leads its own space programme - sent the next missile VS30 from Barreira do Inferno in Rio Grande do Norde.

In November 2007, one month before VS30 launch - both countries signed an agreement to jointly prepare a satellite which will provide information on "optical characteristics" of the oceans on a global scale, which might be used in oceanography and climatology. It was a breakthrough event for Argentinian and Brazilian cooperation, and has been developing with some changeable dynamics since 1998.

A common Argentinian and Brazilian mission SABIA-MAR (in Spanish: Satélite Argentino-Brasileño de Informaciones sobre Recursos Hidricos, Agricultura y Medio Ambiente) is an important scientific research project, which is supposed to do an ocean ecosystems research as well as marine habitats, seashores and water endangering mapping. Argentina cooperates with an Italian space agency, they are working together on the Cosmo-Skymed satellite. The first Argentinian and Italian satellite was launched in 2007 with the use of Californian base Vanderberg Air Force. It is a part of Italian and Argentinian satellite system, used in emergency management (in Spanish: Sistema ítalo-argentino de satélites para la gestión de emergencias) - a satellite monitoring system SOACOM 1A (in Spanish: Satélite Argentino de Observación Con Microondas; works on this project begun in 2015) and SOACOM 1B (started in 2016), which aim is to prevent and reduce results of environmental disasters [15].

Peru has a much more primitive space programme, however it has recorded a few successes. In December 2006, the first Peruvian space probe, PAULET 1, was launched from Punta Lobos base in Pucusana (south of Lima). The mission lasted two years, and has been used to develop devices and software, which can measure conditions in the upper layers of the atmosphere, including temperature, humidity and pressure. From that moment, according to the announcement of Colonel Wolfgang Dupeyrat, the head of the Peruvian Space Agency CONIDA, Peru tries to develop its own space programme [16]. The first Peruvian satellite is CHASQUI I - a nanosatellite weighting 1 kilogram, which was launched manually during a spacewalk from the International Space Station (ISS) on 18th August 2014. The satellite was equipped with two cameras which transmitted photos of the Earth visible in infrared. What is interesting, the CHASQUI I was designed by students from Universidad Nacional de Ingenieria in Lima, as a part of an educational project. [17]. From that moment, the National Technical University of Lima (in Spanish: Universidad Nacional de Ingenieria) in cooperation with the Russian University in Kursk, works on the second satellite, CHASQUI II, a microsatellite weighting about 30 kilograms (initial plans foresaw launching in 2014, but financial problems forced engineers to postpone it in time). The satellite is designed 
to monitor deforestation and the threat of natural disasters as well as to collect data for oceans research. Peru and Russia have a long history in cooperation in research, not only not only in space but also in other ventures, such as military cooperation: Peru imports Russian military equipment, including helicopters [18]. In 2008 Venezuela formalised cooperation with the Chinese Xichang Space Centre in space research on Miranda satellite [19]. And from 2011 Bolivia together with the China Aerospace Science and Technology Corporation (CASTC) works on the first Bolivian satellite Tupak Katari. The project Tupak Katari is going to cost 300 million USD. Bolivia promised to give 45 million USD, the rest is going to come from the loans provided by Chinese banks [20].

Since the mid-1990s Mexico also had an advanced plans regarding the placement of telecommunications satellites SatMex (in Spanish: Satélites Mexicanos) [21]. It was seeking technical and financial cooperation to implement already began projects [22]. The first Mexican satellite UNAMSAT-1 was destroyed during take-off in 1996, the second satellite UNAMSAT-B worked on the orbit for one year. In 2014 SatMex was bought for 831 million USD by Europen Eutelmex (European Telecommunications Satellite Organization), located in France. Since then, Mexico has been developing joint projects and cooperating on the launch of next Eutelmex satellites [23].

\section{BRAZIL'S NEW ERA IN SPACE RESEARCH}

Among Latin American countries, Brazil is the most advanced economy in research and development (R\&D) with a high potential for innovation and competitiveness. Particularly noteworthy is the Brazilian aviation sector, one of the most innovative sectors of the economy in developing countries. High expectations for the development of space research are connected with new initiatives of the Brazilian Alcântara Centre [24]. The greatest problem Alcântara has to deal with is the chronic shortages of missiles, which could be launched. At the moment Brazil is not able to produce such missiles, because of financial and technological issues, and decided to strengthen the cooperation with Russia and Ukraine, by implementing international programmes to build six rockets. Within the programme, work is being carried out on the construction of both small satellites for low Earth orbit (LEO) as well as heavy geosynchronous communication satellites.

The Brazilian-Ukrainian joint venture, established in 2003 as a long-term joint research programme funded equally by both partners, aims to launch a new racket based on Cyclone-4 system from Alcântara. It is supposed to be a modernized version of Cyclone-3 missile, constructed in Ukraine in Soviet times. It is supposed to carry a charge weight of 5500 kilograms in the case of low Earth orbit (LEO) and 1700 kilograms in the case of geosynchronous transfer orbit (GTO). The programme was formally launched in 2010 and was scheduled to end in 2014, however due to financial problems caused by the economic crisis, satellites have not been launched yet. Out of the 488 million USD needed for that purpose Brazil invested the largest part. What is more, Brazil had to cope with problems such as land ownership, deforestation and the construction of a relevant starter centre, what significantly delayed all the preparations [25]. 
On the other hand, the Brazilian-Russian cooperation is being developed under the Southern Cross initiative since 2005. The programme involves the Brazilian Space Agency (AEB) and the General Board of Space Technology (in Portuguese:Comando-Geral de Tecnologia Aerospacial, CTA), which is the major military research centre for space exploration and aviation, and is a part of the Brazilian Air Force.

Southern Cross is a much more ambitious initiative than Cyclone-4, and its aim is to create missiles able to carry the load weighting from 400 kilograms to 4 tones. Missiles from Southern Cross family are called:

- Alpha (light) - an upgraded version of Brazilian VLS-1 satellite

- Beta (light)

- Gamma (light) - the total cargo weight of more than 1 tone on the geostationary orbit (GEO)

- Delta (medium) - the total cargo weight of 1.7 tone on the geostationary orbit (GEO)

- Epsilon (heavy) - the total cargo weight of 4 tons on the geostationary orbit (GEO).

Within the programme, Russians assist the AEB in improving the reliability of solid fuel engines. Two more advanced types of VLS-1 (Beta and Gamma) are going to be equipped with liquid fuel engines. The Russian Angara satellite, equipped with RD-191 engine, is to be the starting point for heavier rockets construction.

The main advantage of missiles constructed within the Southern Cross initiative is the fact they use a relatively low toxic fuels. The Ukrainian Cyclone-4 uses toxic fuels (1.1-dimethylhydrazide and nitric oxide, which are harmful to health, are used for production of these fuels), which is one of the reasons why those missiles are no longer used on the Baikonur Cosmodrome ${ }^{1}$.

However, like the Cyclone-4, the Southern Cross initiative was not finished in time. Many delays were caused by lack of funding and the difficulties of the Russians with the completion of their own Angar project, which was supposed to be the basis for further joint work. The end of the project was postponed by two years, to 2022 .

In order to increase the quality of research and the diversity of solutions, Brazil seeks different partners for its space projects. It is worth noting the interesting and promising initiative implemented with the Polish partners. Polish-Brazilian Center of Excellence in Aviation and Space High Technology, which since 2015 coordinates the scientific cooperation between the Institute of Aviation in Warsaw and the University in Brazil (Universidade de Brasilia). The tasks implemented by the Centre include among other joint research on modern materials and space technologies or organisation of Polish-Brazilian missile and space-based workshops. [26] Other promising initiative of the co-operation between Polish and Brazilian research institutes and industry is the agreement signed by then President of the Polish Space Agency Prof. Banaszkiewicz with the Brazilian Space Agency during the $1^{\text {st }}$ Polish-Brazilian Conference on Science and Technology, held in September 2015 in Brasilia. 


\section{CONCLUSION}

Despite a significant financial and intellectual commitment of the participating countries and development of long-term space research strategies, Latin American space technologies are still at an early stage compared to the major powers in space research. Facing insufficient funding, Latin America cannot afford conducting costly projects and will continue to rely on cooperation with major powers from outside the region - the United States, China, Russia and France - in terms of knowledge, technology, innovation and development opportunities. It will take many years and a great financial need for Latin American space programmes to achieve the maturity and scientific excellence necessary to independently monitor the militarisation of space, not to mention to reduce their dependence on the current space powers. Nevertheless, countries such as Brazil, Argentina, Venezuela and Peru are examples that Latin American space programmes are advanced enough to deserve the attention of by space exploration powers, including NASA. And the development of space technologies in Latin America might be seen as both a long- and short-term source of innovation due to the diffusion of advanced technologies to other areas [27].

The development of endogenous space technology in Latin America has several aspects. It is obvious that there is an increase in innovation, improvement of key competences of human capital, and transfer of technology to other areas. Space technologies are an important tool which improves telecommunications in the isolated regions, as well as supports environment monitoring, including the detection and early warning systems for natural disasters and information about varied environmental conditions. At the same time, space technologies can be used relatively easy for military and paramilitary purposes, not only for national security, but also for espionage and terrorism, including through the intrusion into closed safety nets [22]. Taking arms race into consideration, which pace accelerated significantly in recent years in some parts of the world, responsible (and extremely expensive) oversight by countries, local governments, and international community is necessary to ensure that space technology created in Latin America, for example by way militarisation of space, will not become another way to bring back instability in the region.

The Latin American space programmes are and will still be dependent on technical help and cooperation with advanced countries, which have already achieved an adequate level of knowledge and skills. None of the Latin American space agencies decided to join the International Space Exploration Coordination Group (ISECG), in which, besides NASA, 13 agencies from different countries participate [28] $]^{2}$. ISECG platform was established in 2007 in response to needs formulated in the programme document: "The Global Exploration Strategy: The Framework for Coordination" and is the biggest initiative of this type in the world [29]. Nonetheless, even now Latin American space programmes have a chance to change the matter of security in the region, especially if they are dependent on a responsible civil supervision in each country, which will be able to prevent their militarisation.

2 There is a numer of agencies in the frames of the ISECG: ASI (Italy), BNSC (Great Britain), CNES (France), CNSA (China), CSA (Canada), CSIRO (Australia), DLR (Germany), ESA (European Space Agency), ISRO (India), JAXA (Japan), KARI (Republic of Corea), NASA (US), NSAU (Ukraine), Roscosmos (Russia). 
Experts from different parts of the world have various opinions about space programmes held in Latin America and its necessity. Some say that if considering the current economic and social development of Latin America, in particular poverty and economic inequalities, the enormous financial resources for space programmes could be better utilized for the development of the country in critical areas. For example through advanced agriculture technology, social programmes or creating new jobs [22]. Other expert argue that these space programmes are essential for Latin America to achieve autonomy from major world powers, including the United States in particular, in the area of space research. This can be a very important element in the geopolitical mosaic of global forces. Brazilian geopolitical aspirations are somehow mirrored in the importance of space research, what is indicated in the report of the Centre for Strategic and International Studies (CSIS) from 2010:

"Civilian space research continues to be a prerequisite for achieving the status of a global power. This lesson has been well worked out by Brazil. [...] The need for [independent access to space] is an area that is a priority for Brazil, as evidenced by its importance in the 2008 National Defence Strategy. Brazil wants not only to develop the technical capabilities of launching satellites, but also intends to build its own satellites for Earth observation and communication capabilities." [2]

It is worth remembering that the Latin American space programmes are not automatically oriented towards militarisation of space and do not mean the arms race; non-military usage of technology, including improved telecommunications and environmental monitoring or early warning of natural disasters is enormously needed in the region, which covers both the Andes and the Amazon. Furthermore, space research is one of the best innovation vector in the region.

\section{REFERENCES}

[1] Gocłowska-Bolek J., 2015, "Fostering economic and social innovativeness to address development challenges in Latin America", in: "Openness, innovation, efficiency and democratization as preconditions for economic development". Proceedings of the 11th International Conference of ASECU, ISBN 978-83-65173-37-9, Cracow, p. 201-209.

[2] Mendelson Forman J., Sabathier V., Faith G.R., Bander A., 2009, “Towards the Heavens. Latin America's Emerging Space Programs", CSIS, Washington.

[3] https://www.nasa.gov/centers/johnson/home/index.html [access: 2.02.2017].

[4] Mercopress, 2011, "Argentina, with Brazilian support proposes a South American Space agency”, 1.08.2011., http://en.mercopress.com/2011/09/01/argentina-with-brazilian-supportproposes-a-south-american-space-agency [access: 2.02.2017].

[5] Sánchez A., 2008, "Space Technology Comes to Latin America: Part of the Hemisphere's Road to Autonomy", COHA Report, http://www.coha.org/space-technology-comes-to-latinamerica-part-of-the-hemisphere's-road-to-autonomy/ [access: 2.02.2017]. 
[6] UNESCO, 2016, “Science Report. Toward 2030”, Paris.

[7] https://www.nasa.gov/news/budget/index.html

[8] PAP, 2015, „SzefPolskiejAgencji Kosmicznej: agencja może przynieść Polsce korzyści”, 2015-06-14. http://naukawpolsce.pap.pl/aktualnosci/news,403735,szef-polskiej-agencji-kosmicznej-agencjamoze-przyniesc-polsce-korzysci.html [access: 20.01.2017].

[9] http://www.invap.com.ar/es/la-empresa/sala-de-prensa/novedades/637-acuerdo-entre-argentinay-brasil-para-la-construccion-de-dos-reactores-de-investigacion-.html [access: 20.01.2017].

[10] http://www.invap.com.ar/es/espacial-y-gobierno/proyectos-espaciales/satelite-arsat.html [access: 20.01.2017].

[11] http://www.invap.com.ar/en/aerospace-and-government/government-projects/argentine-airrobotic-system-sara-in-spanish.html [access: 20.01.2017].

[12] http://www.invap.com.ar/en/aerospace-and-government/aerospace-and-government-area/ introduction-aerospace.html [access: 20.01.2017].

[13] Arias D., 2015, „Escaleras al cielo, peldaño a peldaño (Serie Tronador II)”, Portinos https://portinos.com/14577/escalera-al-cielo-peldano-a-peldano-serie-tronador-ii [access: 20.01.2017].

[14] http://www.sipam.gov.br [access: 19.01.2017].

[15] http://www.aeb.gov.br/brasil-e-argentina-concluem-fase-a-do-projeto-sabia-mar/ [access: 20.01.2017].

[16] http://www.conae.gov.ar/index.php/espanol/misiones-satelitales/saocom/objetivos [access: 20.01.2017].

[17] http://www.chasqui.uni.edu.pe [access: 20.01.2017].

[18] http://www.deltronnews.com/Satélite-peruano-Chasqui-II-estará-en-órbita-el-2014 [access: 20.01.2017].

[19] http://news.xinhuanet.com/english/sci/2012-02/11/c_131404796.htm [access: 2.02.2017].

[20] http://news.xinhuanet.com/english2010/china/2011-08/10/c_131041506.htm [access: 2.02.2017].

[21] http://www.satmex.com.mx [access: 20.01.2017].

[22] Sánchez A., 2012, "Latin America space programs", The Space Review, 27.08.2012., http://www.thespacereview.com/article/2143/1 [access: 2.02.2017].

[23] http://www.eutelsat.com/en/home.html [access: 2.02.2017].

[24] MessierD.,2011,„WillanewspacepowerrisealongtheAtlantic?”,TheSpaceReview,15.08.2011., http://www.thespacereview.com/article/2143/1 [access: 10.03.2017].

[25] https://www.kyivpost.com/article/content/ukraine-politics/first-launch-of-ukrainian-brazilianrocket-schedul-114278.html [access: 10.03.2017].

[26] http://ilot.edu.pl/wspolpraca/partnerzy-zagraniczni/uniwersytet-w-brasilii/ [access: 4.07.2017].

[27] Gocłowska-Bolek J., 2017, „Ameryka Łacińska w poszukiwaniu nowej strategii rozwoju” („Latin America in the search of a new development strategy”), Biblioteka Iberyjska, Warsaw.

[28] https://www.nasa.gov/exploration/about/isecg/\#.WY7rT7tuKM8 [access: 12.04.017].

[29] ESA, 2007, „The Global Exploration Strategy: The Framework for Coordination, European Space Agency", April 2007, http:/www.globalspaceexploration.org/c/document_library/get_ file?uuid=119c14c4-6f68-49dd-94fa-af08ecb0c4f6\&groupId=10812 [access: 10.04.2017]. 


\section{LATYNOAMERYKAŃSKIE BADANIA KOSMICZNE JAKO MECHANIZM REGIONALNEJ I PONADREGIONALNEJ WSPÓLPRACY BADAWCZEJ}

\section{Streszczenie}

W Ameryce Łacińskiej wskazuje się dziś na naukę, technologię i innowacje jako czynniki determinujące tempo rozwoju, zaś priorytetem wielu rządów jest budowanie gospodarki opartej na wiedzy. Jednym z obszarów o największym potencjale innowacyjności i największym stopniu zaawansowania technologicznego są badania kosmiczne. Latynoamerykańskie badania kosmiczne cieszą się kilkudziesięcioletnią tradycją i zasłużoną marką na forum międzynarodowym. Miano regionalnego lidera innowacyjności w tym zakresie należy się Brazylii, jednak również Argentyna, Peru i Wenezuela przez lata zdołały dokonać interesujących osiągnięć. Badania kosmiczne, z racji stosowanych rozwiązań o możliwie najwyższym stopniu doskonałości naukowej oraz konieczności zaangażowania najlepszych specjalistów są źródłem dyfuzji wiedzy i innowacji do innych dziedzin nauki oraz przemysłu, ale jednocześnie wymagają ogromnych nakładów finansowych, często przekraczających możliwości pojedynczego kraju. W dobie globalizacji, która m.in. wymusza stosowanie coraz bardziej zaawansowanych i coraz bardziej kosztownych technologii, nieuniknione jest z jednej strony podjęcie konkurencji w wymiarze globalnym, a z drugiej zacieśnianie współpracy badawczej z partnerami zagranicznymi. W artykule wykazano, że latynoamerykańskie badania kosmiczne stanowią efektywny mechanizm budowania powiązań naukowych pomiędzy krajami regionu, ale też $\mathrm{w}$ partnerstwie ponadregionalnym.

Słowa kluczowe: Ameryka Łacińska, Brazylia, badania kosmiczne, innowacyjność, współpraca badawcza. 